\title{
MANFAAT EKONOMIS DISEMINASI TEKNOLOGI MODIFIKASI CUACA DI DAERAH ALIRAN SUNGAI CITARUM
}

\author{
F. Heru Widodo ${ }^{1}$ dan Tukiyat ${ }^{2}$
}

\begin{abstract}
This study aimed to calculate benefit cost ratio of the implementation of Weather Modification Technology and to learn about production costs, the amount of water needed for irrigation, the price of grain per ton, the production of grain per hectare, so the value of $B$ / $C$ of the implementation of the TMC as a real value which can responsibility to the public. Specifically this study aims to calculate the economic value the application of the weather modification technology on the Citarum River Basin of West Java from the aspects of hydropower and agriculture. The research data in the form of secondary data that are time-series in 2007. The research data in the form of secondary data from the TMC in Das Citarum activities in 2007. The data required for the writing of this paper include: data stream reservoir (DMA, Inflow and Outflow) for TMC events take place, among others: Additional data potential of electric energy; cost data for agricultural production per hectare per cropping; data size of the volume of water used to produce $1 \mathrm{kWh}$; electricity prices per $\mathrm{kWh}$; data estimation of rice production per hectare; estimate the amount of agricultural water demand per hectare per harvest, the price of milled rice per kg dry; cost of operation TMC. Data collecting techniques through interviews with farmers groups in the area of Subang, Karawang, Indramayu supported by studies in the literature after the focus of research related to information regarding the economic aspects of technology Mudifikasi weather. The results showed that the additional amount of water activity of TMC in Das Citarum 2007 as many as 716.92 million m3. With the addition of water during TMC activities can generate as much electricity as the number of kWh 447.284.99. Benefit of TMC in hydropower sector $R p .85,252,520,810$ and benefits in the agricultural sector $R p .610$ 643840 116. Total economic benefits of TMC activity Rp. 695896360 926, - The result analysis $B / C$ ratio of 233:1. This means that every expenditure amounting to $R p 1$, - you will get an income of Rp. 233
\end{abstract}

\section{Intisari}

Penelitian ini bertujuan untukmenghitung B/C ratio daripelaksanaan Teknologi Modifikasi Cuaca melalui parameter-parameter nilai biaya produksi, banyaknya air yang dibutuhkan untuk pengairan, harga gabah per ton, produksi gabah per ha, sehingga nilai B/C dari pelaksanaan TMC sebagai nilai riil yang sudah bisa dipertangungjawabkan kepada publik. Secara khusus penelitian ini bertujuan menghitung nilai ekonomis penerapan Teknologi Modifikasi Cuaca di Daerah Aliran Sungai (DAS) Citarum Jawa Barat dari aspek PLTA dan pertanian. Data penelitian berupa data sekunder dari hasil kegiatan TMC di Das Citarum tahun 2007. Adapun data yang dibutuhkan dalam penulisan paper adalah data aliran Waduk (DMA, Inflow dan Outflow) selama kegiatan TMC berlangsung antara lain data: tambahan potensi energi listrik; besarnya volume air yang digunakan untuk menghasilkan $1 \mathrm{kWh}$; harga listrik per kWh; estimasi hasil produksi padi per hektar; biaya produksi pertanian per ha per tanam; estimasi besarnya kebutuhan air pertanian per hektar per panen; harga gabah kering giling per kg; biaya pelaksanaan TMC.

\footnotetext{
${ }^{1}$ Perekayasa Madya UPT Hujan Buatan, BPP Teknologi, Jakarta

${ }^{2}$ Perekayasa Madya UPT Hujan Buatan, BPP Teknologi, Jakarta.
} 


\begin{abstract}
Teknik pengumpulan data melalui survei lapangan dan wawancara mendalam dengan kelompok tani di daerah Subang, Karawang, dan Indramayu dengan didukung studi literatur yang terkait dengan informasi mengenai aspek ekonomi Teknologi Mudifikasi cuaca. Hasil penelitian menunjukkan bahwa jumlah tambahan air kegiatan TMC di Das Citarum tahun 2007 sebanyak 716,92 juta m3. Dengan tambahan air tersebut dapat menghasilkan jumlah $\mathrm{kWh}$ listrik sebanyak 447.284.99 kWh. Dari tambahan air tersebut dapat memberikan manfaat ekonomi pada sektor PLTA sebesar Rp. 85.252.520.810,dan sektor pertanian sebesar Rp. 610.643.840.116,- Manfaat ekonomi secara total kegiatan TMC sebesar Rp. 695.896.360.926,- Dari hasil tersebut secara ekonomis besarnya nilai B/C rasio sebesar 233:1. Hal ini berarti setiap pengeluaran sebesar Rp.1,- maka akan dapat diperoleh pendapatan sebesar Rp. 233,--
\end{abstract} Kata Kunci: Analisis Ekonomis, Benefit Cost Ratio, Diseminasi Teknologi Modifikasi
Cuaca

\section{PENDAHULUAN}

Fenomena El Nino hampir setiap tahun terjadi di Indonesia dan dampaknya sangat dirasakan terutama pada sektor pertanian dan ketahanan pangan secara nasional. Kemarau yang berkepanjangan dapat mengakibatkan terjadinya gagal panen, kebakaran hutan, terganggunya pembangkit listrik tenaga air pada beberapa wilayah di Indonesia. Jika dirunut lebih jauh, penyebab krisis pangan di Indonesia, di masa-masa sebelumnya dan mungkin di masa mendatang adalah konsekuensi dari pilihan bangsa Indonesia sendiri yang selama ini terlalu menggantungkan penyediaan pangannya pada impor. Hal ini terbukti dari angka impor pangan Indonesia yang terus meningkat dari tahun ke tahun. Tahun 2007, pemerintah memutuskan mengimpor komoditi pangan, meliputi 1,5 juta ton beras dan 1,5 juta ton kedelai. Untuk beras, angka tersebut naik sekitar $78,5 \%$ dari tahun 2006 yang hanya sebesar 840 ribu ton. Sedangkan untuk kedelai, angka tersebut naik $25 \%$ dari tahun 2006 yang berjumlah 1,2 juta ton (Serikat Petani Indonesia, 2007). Hal ini tentu sangat berbahaya bagi kemandirian dan ketahanan pangan Indonesia, karena ketahanan pangan yang kuat dicirikan oleh kemandirian pangan yang kuat. Faktor anomali cuaca yang terjadi disebut-sebut sebagai salah satu penyebab terjadinya gagal panen dan berimbas pada melonjaknya harga kebutuhan pokok tersebut.

Pada awal tahun 2007 Pemerintah Republik Indonesia telah mencanangkan Program Peningkatan Produksi Beras Nasioal 2 Juta Ton. Berkaitan dengan Program Nasional yang telah dicanangkan oleh Pemerintah tersebut, Pemerintah telah melakukan beberapa persiapan dengan baik, diantaranya adalah dengan pemantapan ketersediaan air pada waduk-waduk strategis yang merupakan sumber air untuk kebutuhan irigasi bagi lahan pertanian pada daerah - daerah sentra produksi padi nasional, seperti Waduk Karangkates
(Jawa Timur), Waduk Kedungombo, Wonogiri, Sempor dan Wadaslintang (Jawa Tengah), Waduk Saguling, Cirata dan Ir. H. Juanda (Jawa Barat) dan Waduk Batutegi (Lampung).

Berdasarkan informasi dari Departemen Pekerjaan Umum memberikan fakta bahwa ketersediaan air pada beberapa waduk di Indonesia pada awal tahun 2007 berada pada kondisi defisit (di bawah normal), tidak terkecuali pada wadukwaduk strategis yang sudah disebutkan di atas. UPT Hujan Buatan BPPT melalui forum Masyarakat Hidrologi Indonesia (MHI) pada bulan Januari 2007 juga menambahkan informasi mengenai gambaran umum kondisi sumber daya air di Indonesia yang cenderung akan kering khususnya di Pulau Jawa untuk tahun 2007. Informasi ini mendapattanggapan serius dari Departemen Pekerjaan umum dan Pertanian berkenaan dengan pencapaian target Peningkatan Produksi Beras 2 Juta Ton yang dibebankan oleh Pemerintah kepada Departemen Pertanian.

Atas prakarsa $\mathrm{MHI}$ pada tanggal 28 Pebruari 2007 diselenggarakan seminar bertemakan Kondisi Sumber Daya Air Untuk Pencapaian Peningkatan Produksi Beras 2 Juta Ton Tahun 2007, bertempat di Departemen Pertanian Jakarta. Dari perumusan hasil seminar tersebut, MHI memberikan rekomendasi kepada Pemerintah melalui Departemen Pekerjaan Umum dan Departemen Pertanian, bahwa untuk keberhasilan program tersebut maka diperlukan dukungan ketersediaan air yang memadai terutama di sentra produksi padi, disamping juga dukungan yang berupa penggunaan sarana produksi pertanian dan perbaikan jaringan irigasi. Salah satu upaya untuk mengatasi permasalahan kurangnya pasokan sumberdaya air dan ketersediaan air di permukaan adalah pengisian waduk-waduk melalui penerapan Teknologi Modifikasi Cuaca (TMC).

Menindaklanjuti rekomendasi dari hasil seminar MHI tersebut, Menteri Pertanian Republik Indonesia menerbitkan Surat Menteri Pertanian 
Republik Indonesia Nomor : 15/SR.160/M/1/2007 tanggal 26 Januari 2007, perihal Teknologi Modifikasi Cuaca / Hujan Buatan. Selanjutnya Surat dari Menteri Pertanian Republik Indonesia tersebut mendapat dukungan dari Menteri Pekerjaan Umum Republik Indonesia dengan diterbitkannya Surat Menteri Pekerjaan Umum Republik Indonesia Nomor : IP.05.06-Mn/78 tanggal 7 Maret 2007, perihal Program Teknologi Modifikasi Cuaca / Hujan Buatan Pada Waduk-waduk Strategis. Melalui surat ini Menteri Pekerjaan Umum Republik Indonesia menyampaikan rencana pengisian waduk-waduk melalui Teknologi Modifikasi Cuaca (TMC) atau Hujan Buatan untuk menunjang ketersediaan air waduk, khususnya yang melayani daerah-daerah sentra produksi padi.

Melalui kelembagaan BPPT, khususnya UPT Hujan Buatan telah secara aktif berperan membantu beberapa daerah yang mengalami kekeringan panjang dengan membuat hujan buatan. Dengan Teknologi Modifikasi Cuaca (TMC)-nya UPT ini telah berhasil mengurangi permasalahan di daerah yang diakibatkan oleh terjadinya kemarau panjang, seperti mengatasi kebakaran hutan dan menambah volume air di beberapa waduk utama di Jawa. Secara umum teknologi ini telah berhasil didayagunakan untuk kepentingan mesyarakat luas. TMC merupakan teknologi alternatif dalam upaya penyediaan air di suatu wilayah, mempunyai nilai strategis dalam menghadapi masalah yang terkait dengan penyimpangan iklim. Dengan menerapkan TMC diharapkan dapat menekan atau mengurangi dampak yang ditimbulkan akibat adanya penyimpangan iklim seperti kondisi musim kemarau yang ekstrem. Namun demikian kebijakan desiminasi TMC tersebut belum memasyarkat secara umum dimana hanya beberapa instansi dan masyarakat tertentu saja yang bisa memahami akan manfaat TMC untuk pembangunan. Hal ini juga dirasakan oleh beberapa peneliti UPT Hujan Buatan dalam setiap malakukan diseminasi TMC pada beberapa daerah yang belum semuanya menerima TMC sebagai suatu teknologi yang dapat memberikan solusi dalam mengantisipasi dampak perubahan iklim global yang ditandai dengan gejala anomali tersebut.

Dalam rangka untuk meyakinkan kepada masyarakat maupun mitra kerja UPT hujan Buatan sering dihadapkan pada masalah tantangan pertanyaan tentang efisiensi dan nilai ekonomis pelaksanaan kegiatan hujan buatan selalu mengemuka setiap dilaksanakan kegiatan penerapan TMC (Teknologi Modifikasi Cuaca). Untuk menilai apakah kegiatan hujan buatan cukup efisien, dapat dilakukan dengan menghitung nilai ekonomis operasional TMC dengan tinjauan aspek ekonomi melalui perhitungan nilai benefit Cost Ratio (B/C Ratio) dari nilai manfaat untuk listrik
PLTA dan pertanian selama kegiatan berlangsung.

Tulisan dari hasil penelitian ini bertujuan untuk menghitung $\mathrm{B} / \mathrm{C}$ ratio dari pelaksanaan Teknologi Modifikasi Cuaca dengan menghitung langsung parameter-parameter yang dulunya masih berupa asumsi seperti nilai biaya produksi, banyaknya air yang dibutuhkan untuk pengairan, harga gabah per ton, produksi gabah per Ha dll, sehingga nilai $\mathrm{B} / \mathrm{C}$ dari pelaksanaan TMC benar-benar nilai riil yang sampai hari ini belum pernah dihitung. Tujuan dari penelitian terapan ini adalah menghitung nilai ekonomis penerapan Teknologi Modifikasi Cuaca di Daerah Aliran Sungai Citarum Jawa Barat dari aspek PLTA dan pertanian.

\section{DATA DAN METODE PENELITIAN}

Data penelitian ini menggunakan data hasil kegiatan TMC di Das Citarum tahun 2007. Adapun data yang dibutuhkan untuk penulisan paper ini meliputi data: aliran Waduk (DMA, Inflow dan Outflow) selama kegiatan TMC berlangsung antara lain data: tambahan potensi energi listrik; biaya produksi pertanian per ha per tanam; besarnya volume air yang digunakan untuk menghasilkan 1 kWh; harga listrik per kWh; estimasi hasil produksi padi per hektar; estimasi besarnya kebutuhan air pertanian per hektar per panen; harga gabah kering giling per kg; biaya pelaksanaan TMC

Pengumpulan data dilakukan melalui survei lapangan dan wawancara mendalam dengan kelompok tani di daerah Subang, Karawang, Indramayu dan studi literatur yang terkait dengan informasi mengenai aspek ekonomi Teknologi Mudifikasi cuaca.

Nilai manfaat ekonomis operasional TMC dianalisis dari aspek pamanfaatan air dari aspek PLTA dan aspek pertanian dengan pendekatan model rasio manfaat biaya (benefit cost ratio). Metode $\mathrm{B} / \mathrm{C}$ rasio adalah suatu perbandingan (rasio) nilai ekuivalen dari manfaat terhadap nilai ekivalen dari biaya-biaya. Benefit didefinisikan sebagai konsekuensi-konsekuensi kegiatan TMC yang diinginkan oleh publik. Sedang biaya adalah pembayaran atau pengeluaran keuangan yang dibutuhkan untuk operasional TMC. Menurut Reksohadiprodjo (1989), efisiensi merupakan konsumsi barang dan jasa secara maksimum dengan adanya sumberdaya tertentu, atau pemanfaatan sumberdaya secara minim untuk memproduksikan barang dan jasa tertentu.

Setelah dihitung harga air dilanjutkan dengan penghitungan nilai Benefit Cost Ratio (B/C ratio), sehingga bisa menjawab apakah pelaksanaan kegiatan TMC selama ini cukup efisien jika ditinjau dari biaya yang dikeluarkan dengan hasil air yang didapatkan. Apabila besarnya hasil air yang dikonversi ke harga listrik dan produksi pertanian 
selama kegiatan hujan buatan lebih besar dibanding dengan biaya yang dikeluarkan selama kegiatan maka kegiatan hujan buatan tersebut dapat dinilai efisien dan ekonomis begitu juga sebaliknya.

Hasil tambahan air selama kegiatan TMC dapat diekivalenkan dengan harga produksi listrik yang secara matematis dapat dirumuskan:

Dimana : $\frac{X}{Y} \times$ harga per $1 \mathrm{kWh}$

$\mathbf{X}=$ jumlah tambahan air $\left(\mathbf{M}^{3}\right)$

$\mathrm{Y}=$ kebutuhan air untuk $1 \mathrm{kWh}$

Sedang untuk menghitung besarnya nilai manfaat TMC dari aspek pertanian secara matematis dirumuskan:

$$
\frac{X}{Y} \times \text { jumlah produksi per ha }
$$$$
\text { = harga gabah kering giling }
$$

Dimana:

$\mathrm{X}=$ Jumlah tambahan air $\left(\mathrm{M}^{3}\right)$

$\mathrm{Y}=$ Kebutuhan air $/ \mathrm{Ha}$

Analisis ekonomis manfaat TMC diukur dengan pendekatan rasio manfaat biaya (Benefit Cost Ratio) secara matematis dirumuskan:

$B C$ Ratio $=\frac{P V \text { Manfaat KegiatanTMC }}{\text { PV Biaya Selama KegiatanTMC }}$

Dimana:

$\mathrm{B} / \mathrm{C}$ rasio (benefit cost ratio) $=$ ratio penerimaan terhadap pengeluaran

PV Benefit (present value of benefit) = nilai sekarang total pendapatan TMC

CPV $($ present value of cost $)=$ nilai sekarang dari total biaya TMC

Kriteria keputusan:

- Apabila nilai $\mathrm{B} / \mathrm{C}$ rasio > $>$, maka kegiatan operasional TMC tersebut layak (feasible) secara ekonomis. Artinya tedapat selisih positif antara manfaat dengan biaya operasional.

- Apabila nilai $\mathrm{B} / \mathrm{C}$ rasio $<1$, maka kegiatan operasional TMC tersebut tidak layak secara ekonomis. Artinya tedapat selisih negatif antara manfaat dengan biaya operasional

\section{HASIL PENELITIAN DAN PEBAHASAN}

\subsection{Manfaat Ekonomi TMC ditinjau dari aspek Tenaga Listrik (PLTA)}

Sumber energi listrik dapat diperoleh dari beberapa sumber seperti dari air yaitu Pusat Listrik Tenaga Air, dari solar yaitu Pusat Listrik Tenaga Diesel, dari batu bara yaitu Pusat Listrik Tenaga Uap, dari gas bumi yaitu Pusat Listrik Tenaga Gas
Uap, dari angin yaitu Pusat Listrik Tenaga Bayu dan Nuklir yaitu Pusat listrik Tenaga Nuklir. Dari beberapa sumber energi listrik ini, PLTA merupakan sumber energi yang paling murah dan ramah lingkungan.

Untuk dapat menghitung asas manfaat TMC dari sektor listrik PLTA dan sektor pertanian diperlukan informasi besarnya tambahan aliran untuk masing-masing Waduk yaitu Waduk Saguling, Cirata dan Ir. H. Djuanda. Jumlah tambahan air selama periode operasi TMC di Das Citarum pada tahun 2007 sebanyak 716,92 juta m3 dengan rincian tambahan air pada periode tanggal 4 - 25 Mei 2007 sebanyak 242,92 juta m³ dan pada periode 23 Oktober - 11 Nopember 2007 sebanyak 474,01 juta $\mathrm{m}^{3}$. Hasil secara rinci dapat ditunjukkan pada Tabel 1. Untuk mengetahui aspek ekonomi TMC dari sektor PLTA dapat diketahui bahwa untuk menghasilkan $1 \mathrm{kWh}$ listrik, PLTA Saguling membutuhkan $1 \mathrm{~m} 3$, PLTA Cirata $3 \mathrm{~m}^{3}$ dan PLTA Ir H. Djuanda membutuhkan air sebesar $6 \mathrm{~m}^{3}$. Dengan tambahan air selama kegiatan TMC berlangsung, maka jumlah kWh listrik yang dapat dihasilkan sebanyak 447.284.99 kWh yang yang dihasilkan dari ketiga waduk tersebut. Besarnya jumlah kWh yang dihasilkan dari tambahan aliran kegiatan TMC Tahun 2007 dapat dilihat pada Tabel 2.

Hasil wawancara dari nara sumber di PJT 2 dan PLN diperoleh informasi bahwa harga 1 kWh listrik dari PLTA untuk PLTA Ir. H. Djuanda, PLTA Saguling dan Cirata sebesar Rp.190,60. Berdasarkan pada hasil listrik sebesar 447.284,99 kWh, maka nilai manfaat TMC dari kegiatan ini sebesar Rp. 85.252.520.810,-. Hasil selengkapnya manfaat TMC dari aspek produksi listrik dapat dilihat pada Tabel 3.

\subsection{Manfaat Ekonomi TMC ditinjau dari aspek Pertanian}

Waduk kaskade Citarum yang beroperasi dalam satu sistem integrasi dari hulu ke hilir. Adapun luas dari dari ketiga waduk tersebut adalah: (1) Waduk Saguling dengan luas DAS $2.283 \mathrm{~km}^{2}$; (2) Waduk Cirata dengan luas DAS $1.778 \mathrm{~km}^{2}$; (3) Waduk Ir. H. Djuanda dengan luas DAS 540 km². Ketiga waduk tersebut merupakan aliran Citarum yang dapat dimanfaatkan untuk kebutuhan irigasi pertanian pengairan dimana aliran rata-rata tahunannya (aliran normal) sebesar 172,24 m³ detik. Adapun kebutuhan pengairan dalam sistem pengairan Jatiluhur adalah untuk irigasi di daerah Tarum barat, Tarum Utara dan tarum Timur dengan luas areal tanam seluas 242.000 ha. Namun demikian untuk mencukupi kebutuhan irigasi pertanian tersebut tidak seluruhnya dipenuhi dari 
aliran dari Sungai Citarum tetapi ada supply dari sumber-sumber setempat yaitu sungai-sungai Bekasi, Cikarang, Cibeet, Cimalaya, Ciherang, Cijengkol, Cigadung dan Cipunegara yang telah diintegrasikan. Kebutuhan air pengairan dari Waduk Ir. H. Djuanda dipadukan dengan penyediaan air dari sumber setempat, bahwa kebutuhan air berbanding terbalik dengan ketersediaan air. Hal ini berarti pada musim hujan kebutuhan air untuk irigasi kecil, sedang pada musim kemarau kebutuhan air untuk irigasi pertanian sangat besar.

Berdasar pada hasil survei lapangan bahwa luas lahan sawah pada wilayah pelayanan untuk irigasi lebih ditekankan pada daerah Jawa Barat dengan lokasi survei Purwakarta, Subang, Pantura (Karawang, Cikampek), dan Indramayu. Data hasil survei lapangan (2009) luas lahan pertanian untuk Kabupaten Indramayu 112.194 ha; Kabupaten Karawang 94.331 ha; Kabupaten Subang 92.624 ha. Secara keseluruhan bahwa luas areal sawah yang dapat dilayani oleh PJT II di bagian utara Bekasi, Karawang, Subang dan Indramayu) sebesar 240.000 ha dan di bagian selatan sebesar 60.000 ha yang dialiri oleh sungai-sungai kecil.

Analisis usaha ekonomi pertanian bertujuan untuk memberikan gambaran keadaan sekarang suatu kegiatan usaha dan menggambarkan keadaan yang akan datang dari perencanaan atau tindakan. Dalam setiap kegiatan atau usaha yang dilakukan haruslah mendapat keuntungan. Oleh karena itu setiap usaha akan mengharapkan imbalan. Imbalan yang dimaksudkan dalam hal ini adalah suatu pendapatan usaha. Pendapatan usaha adalah selisih antara total penerimaan dengan total biaya yang dikeluarkan. Total penerimaan merupakan hasil perkalian dari total produksi yang dihasilkan dengan tingkat harga yang berlaku, sedangkan total biaya adalah semua biaya yang dikeluarkan dalam melakukan proses produksi. Dengan demikian, maka besar kecilnya nilai penerimaan sangat ditentukan oleh jumlah hasil (output) yang diperoleh dari kegiatan produksi dan harga output per satuan.

Pengeluaran dalam usaha tani padi sawah adalah biaya yang dikeluarkan pada saat proses budidaya sampai proses panen, biaya tersebut terdiri dari biaya pembelian benih, biaya pengolahan lahan, biaya pupuk, biaya tenaga kerja dan biaya panen. Komponen biaya merupakan hasil pengadaan dari jumlah fisik yang digunakan dengan harga atau tingkat upah yang berlaku.

Dari hasil kegiatan operasional hujan buatan pada tahun 2007 dapat diperoleh hasil air yang masuk pada ketiga waduk (Saguling, Cirata dan Jatiluhur) sebanyak $716.920 .000 \mathrm{~m}^{3}$. Air tersebut dimanfaatkan untuk mengaliri areal persawahan yang menjadi kesepakatan antara daerah hulu dan hilir tentang irigasi pertanian. Dengan asumsi bahwa setiap ha sawah pertanian membutuhkan air sebanyak $11.000 \mathrm{~m}^{3}$, maka jumlah air yang dihasilkan dari kegiatan TMC dapat mengaliri sawah seluas 65.174,55 ha.

Berdasar pada Tabel 5 seperti tersebut di atas, dengan luas lahan yang dapat diairi dari hasil TMC sebanyak $65.174,55$ ha dan hasil produksi per ha sebesar 6,28 ton dengan harga jual per kg Rp. 2.850,--maka hasil produksi padi sebesar Rp. 1.166.494.014.545,-. Total biaya produksi sebesar Rp. 555.850.170.171,-. Besarnya manfaat ekonomi hasil TMC dari aspek pertanian sebesar Rp. 610.643.844.375,-

\subsection{Analisis Benefit Cost Ratio}

Untuk mengetahui kelayakan ekonomis dari kegiatan operasional TMC dapat diukur dengan indikator $\mathrm{B} / \mathrm{C}$ ratio. Dalam analisa benefit cost ratio dengan mempertimbangkan aliran kas masuk dan aliran kas keluar. Aliran kas masuk merupakan seluruh keuntungan bersih setelah penerimaan dikurangi dengan biaya total. Aliran kas keluar (cash outflow) merupakan seluruh pengeluaran untuk biaya operasional TMC selama periode tersebut. Berdasar pada manfaat ekonomi pada apsek PLTA dan aspek pertanian, maka secara kesuluruhan hasil total dari kegiatan operasi TMC di DAS Citarun pada tahun 2007 diperoleh hasil sebesar Rp. Rp. 695.896.365.185,- sedang biaya yang dikeluarkan oleh users selama kegiatan TMC sebesar Rp. 2.977.123.560,-. Nilaimanfaat ekonomi selanjutnya dikurangi dengan biaya operasional TMC, maka nilai benefit dari hasil kegiatan TMC sebesar Rp. 692.919.241.625,- Dengan demikian, maka nilai B/C rasio dari kegitan operasi TMC adalah 692.919.241.625/2.977.123.560 = 233. Hal ini berarti setiap pengeluaran sebesar Rp.1,- maka akan diperoleh pendapatan sebesar Rp. 233,--

\section{KESIMPULAN, SARAN DAN IMPLIKASI KEBIJAKAN}

\subsection{Kesimpulan}

1. Jumlah Tambahan aliran hasil TMC pada kegiatan penerapan TMC tanggal 04 s.d. 25 Mei 2007 dan 23 Oktober s.d. 11 Nopember sebesar 716.920.000

2. Besarnya manfaat TMC pada sektor PLTA sebesar Rp. 85.252.520.810 sedangkan besarnya manfaat TMC pada sektor pertanian sebesar Rp. 610.643.844.375. Total manfaat ekonomi TMC pada sektor PLTA dan pertanian sebesar Rp. 695.896.365.185. 
3. Besarnya biaya pelaksanaan TMC untuk dua kali kegiatan yaitu kegiatan periode04 - 25 Mei 2007 sebesar Rp. 1.217.641.710 dan periode 23 Oktober - 11 Nopember 2007 sebesar Rp 1.759.481.850. Jumlah total biaya pelaksanaan TMC pada tahun 2007 sebesar Rp. 2.977.123.560 . Jadi besarnya harga air TMC per $\mathrm{m} 3$ adalah Rp. 2.977.123.560 : 716,92 juta m2 yaitu sebesar Rp. 4,15.

4. Nilai $B / C$ ratio dari hasil kegiatan TMC sebesar 233:1. Hal ini berarti setiap pengeluaran sebesar Rp. 1,- akan dapat diperoleh hasil sebesar Rp. 233,-

\subsection{Saran}

1 Waktu kegiatan diusahakan dapat dimulai pada awal tahun, sehingga pelaksanaan kegiatan dapat berjalan lebih baik.

2 Perlu dilakukan juga kajian tekno ekonomi Modifikasi Cuaca di wilayah lain yang potensi dilakukan penerapan TMC, seperti di Jawa Tengan, Jawa Timur, dll.

\subsection{Implikasi Kebijakan}

Hasil analisis ini sebagai masukan bagi pimpinan dalam menentukan pilihan yang tepat dan anggaran dapat dialokasikan secara efektif. Pemilihan alternatif dan penentuan prioritas ini berkontribusi pada pencapaian anggaran berbasis kinerja, yang merupakan salah satu pilar reformasi anggaran.

Dari hasil kesimpulan ini, maka direkomendasikan bahwa penggunaan Teknologi Modifikasi Cuaca menjadi bagian integral dari pengelolaan sumberdaya air pada Wadukwaduk di Indonesia. Hal dipertimbangkan bahwa pemanfaatan TMC memberikan hasil yang positif dengan nilai $\mathrm{B} / \mathrm{C}$ rasio yang besar.

\section{DAFTAR PUSTAKA}

Anonim, 2007. Laporan kegiatan TMC di DAS Citarum Periode 1. UPT Hujan Buatan BPP Teknologi.

Anonim, 2007. Laporan kegiatan TMC di DAS Citarum Periode 2 . UPT Hujan Buatan BPP Teknologi

Dumairy, 1992. Ekonomika Sumberdaya Air. Yogyakarta: BPFE UGM.

Fagi A.M. dan S. Kartaaatmaja. 2004. Teknologi Budidaya padi: Perkembangan dan Peluang. Dalam: Ekonomi Padi dan Beras Indonesia. Penyunting: F. Kasryno, E. Pasandaran dan A.M. Fagi. Badan Penelitian dan Pengembangan Pertanian, Departemen Pertanian, Jakarta.

Keputusan Menteri Negara Riset dan Teknologi/Ketua Badan Pengkajian dan Penerapan Teknologi No : S.K/342/KA BPPT/XII/1985

Pasandaran e., G. Irianto dan N. Zuliasari. 2004. Pendayagunaan dan Peluang Pengembangan Irigasi bagi Peningkatan Produksi Padi. Dalam: Ekonomi Padi dan Beras Indonesia. Penyunting: F. Kasryno, E. Pasandaran dan A.M. Fagi. Badan Penelitian dan Pengembangan Pertanian, Departemen Pertanian, Jakarta.

Reksohadiprodjo, S.,Purnomo Brodjonegoro, AB, 1989. Ekonomi Lingkungan, Suatu Pengantar. Yogyakarta: BPFE UGM. 
Tabel 1. Jumlah Tambahan Air Hasil Evaluasi Kegiatan Teknologi Modifikasi Cuaca di DAS Citarum dari Tanggal 04 - 25 Mei 2007 dan 23 Oktober - 11 Nopember 2007.

\begin{tabular}{|c|c|c|c|}
\hline \multirow{2}{*}{ Nama Waduk } & \multicolumn{2}{|l|}{ Waktu Pelaksanaan } & \multirow{2}{*}{$\begin{array}{c}\text { Hasil Total } \\
\left(\text { Juta m }^{3}\right)\end{array}$} \\
\cline { 2 - 3 } & $\begin{array}{c}\text { Tahap I } \\
(04-25 \text { Mei 07) }\end{array}$ & $\begin{array}{c}\text { Tahap II } \\
(23 \text { Okt- 11 Nop 07) }\end{array}$ & 337.66 \\
\hline Saguling & 137.00 & 200.66 & 278.60 \\
\hline Cirata & 63.90 & 214.70 & 100.55 \\
\hline Ir. H. Juanda & 41.90 & 58.65 & $\mathbf{7 1 6 . 9 2}$ \\
\hline Jumlah & $\mathbf{2 4 2 . 9 1}$ & $\mathbf{4 7 4 . 0 1}$ & \\
\hline
\end{tabular}

Sumber: Tim MONEV Kegiatan TMC di DAS Citarum, 2007.

Tabel 2. Besarnya jumlah kWh hasil Tambahan aliran TMC Tahun 2007

\begin{tabular}{|c|c|c|c|c|}
\hline No & Nama Waduk & $\begin{array}{l}\text { Jumlah Tambahan } \\
\text { aliran (Juta m3) }\end{array}$ & $\begin{array}{l}\text { Kebutuhan air } \\
\text { per kWh }\end{array}$ & Jumlah kWh \\
\hline 1 & Waduk Saguling & 337.66 & 1 & 337.660 .000 \\
\hline 2 & Waduk Cirata & 278.60 & 3 & 92.866 .666 \\
\hline 3 & Waduk Ir. H. Djuanda & 100.55 & 6 & 16.758 .333 \\
\hline & & 716.92 & & 447.284 .999 \\
\hline
\end{tabular}

Sumber: Hasil Perhitungan, 2009.

Tabel 3. Perhitungan manfaat TMC dari produksi listrik PLTA

\begin{tabular}{|c|c|c|c|c|}
\hline No & Nama Waduk & Jumlah kWh & $\begin{array}{c}\text { Harga listrik } \\
\text { per kWh }\end{array}$ & Manfaat TMC (Rp) \\
\hline 1 & Waduk Saguling & 337.660 .000 & Rp.190,60 & 64.357 .996 .000 \\
\hline 2 & Waduk Cirata & 92.866 .666 & Rp.190,60 & 17.700 .386 .540 \\
\hline \multirow[t]{2}{*}{3} & Waduk Ir. H. Djuanda & 16.758 .333 & Rp.190,60 & 3.194 .138 .270 \\
\hline & & 447.284 .999 & & 85.252 .520 .810 \\
\hline
\end{tabular}

Tabel 4: Produksi Padi Di Kabupaten Subang, Indramayu, dan Karawang

\begin{tabular}{|r|l|r|r|r|r|}
\hline \multicolumn{1}{|c|}{ No } & Kabupaten & \multicolumn{1}{c|}{$\begin{array}{c}\text { Produksi } \\
\text { (ton/ha) }\end{array}$} & $\begin{array}{c}\text { Produksi Rata- } \\
\text { rata } \\
\text { (Ton/ha) }\end{array}$ & $\begin{array}{c}\text { Harga jual } \\
\text { (rupiah/ton) }\end{array}$ & $\begin{array}{c}\text { Biaya Produksi } \\
\text { (rupiah/ton) }\end{array}$ \\
\hline 1. & Subang & $7-8$ & 5,25 & 2.800 .000 & 8.365 .000 \\
\hline 2. & Indramayu & $5,5-7$ & 6,25 & 2.800 .000 & 9.370 .000 \\
\hline 3. & Karawang & $6,3-8,4$ & 7,35 & 2.950 .000 & 7.850 .917 \\
\hline 4. & \multicolumn{7}{r|}{ Rata-Rata } & 6,28 & 2.850 .000 & 8.528 .639 \\
\hline
\end{tabular}

Sumber: Hasil Survei Penelitian tahun 2009 
Tabel 5: Perhitungan nilai ekonomi hasil kegiatan TMC di aspek sektor pertanian

\begin{tabular}{|l|l|r|}
\hline \multicolumn{1}{|c|}{ No } & \multicolumn{1}{|c|}{ Keterangan } & \multicolumn{1}{c|}{ Jumlah } \\
\hline 1 & Jumlah hasil TMC (m3) & 716.920 .000 \\
\hline 2 & Kebutuhan air untuk irigasi per ha (m3) & $65.174,55$ \\
\hline 4 & $\begin{array}{l}\text { Jumlah areal lahan yang dapat dialiri } \\
\text { dari hasil TMC (ha) }\end{array}$ & 6,28 \\
\hline 5 & $\begin{array}{l}\text { Rata-rata hasil produksi padi per ha } \\
\text { (ton) }\end{array}$ & 409.296 .145 \\
\hline 6 & $\begin{array}{l}\text { Jumlah produksi padi yang dihasilkan } \\
\text { per ha (ton) }\end{array}$ & 2.850 \\
\hline 7 & $\begin{array}{l}\text { Rata-rata harga jual padi (Gabah } \\
\text { Kering Giling) per kg (Rp) }\end{array}$ & $\mathbf{1 . 1 6 6 . 4 9 4 . 0 1 4 . 5 4 5}$ \\
\hline 8 & Nilai hasil produksi total (Rp) & 8.528 .639 \\
\hline 9 & Rata-rata biaya produksi per ha (Rp) & 610.643 .844 .375 \\
\hline 10 & Total Biaya Produksi (Rp) & $\begin{array}{l}\text { Manfaat Ekonomi hasil TMC aspek } \\
\text { Pertanian (Rp) }\end{array}$ \\
\hline
\end{tabular}

Sumber: Hasil Survei Penelitian tahun 2009

Tabel 5: Perhitungan nilai ekonomi hasil kegiatan TMC di aspek sektor pertanian

\begin{tabular}{|l|l|r|}
\hline \multicolumn{1}{|c|}{ No } & \multicolumn{1}{|c|}{ Keterangan } & \multicolumn{1}{c|}{$\begin{array}{c}\text { Jumlah } \\
\text { (Rupiah) }\end{array}$} \\
\hline 1 & Manfaat ekonomi dari aspek PLTA & 85.252 .520 .810 \\
\hline 2 & Manfaat ekonomi aspek pertanian & 610.643 .844 .375 \\
\hline & Total manfaat ekonomi kegiatan TMC & 695.896 .365 .185 \\
\hline & $\begin{array}{l}\text { Biaya operasional selama kegiatan } \\
\text { TMC }\end{array}$ & 2.977 .123 .560 \\
\hline & Manfaat Bersih hasil kegiatan TMC & 692.919 .241 .625 \\
\hline & \multicolumn{2}{|c}{$233: 1$} \\
\hline
\end{tabular}

Sumber: Hasil Survei Penelitian tahun 2009. 